\title{
One-Night Stands and Long-Term Commitments: Presidential Approval for Sebastián Piñera IN CHILe, 2009-2014*
}

\author{
Aventuras de una noche y compromisos de largo plazo. Aprobación \\ presidencial de Sebastián Pinera en Chile, 2009-2014
}

\author{
PATRICIO NAVIA \\ Liberal Studies, New York University, USA
}

\section{LUCAS PERELLÓ}

Department of Politics, The New School for Social Research, USA

\begin{abstract}
In 2010, Sebastián Piñera (2010-2014) became the first rightwing President of Chile after the dictatorship. His approval fluctuated significantly, experiencing an overall downward decline. Under favorable economic conditions, declining presidential approval must be explained by things other than economic vote. Using logistic regression models and predicted probabilities based on presidential approval polls, we test four hypotheses on the determinants of approval for Piñera: a punishment vote against the Concertación, support tied to economic performance, issue-based support, and the cost of ruling. There is evidence in support of each of the four hypotheses. Although voting for Piñera might have been a one-night stand, economic vote determinants and, to a lesser extent, issue salience and the cost of ruling explain presidential approval under Piñera.
\end{abstract}

Key words: presidential approval, vote intention, economic vote, education, ideology, Chile.

\section{RESUMEN}

En 2010, Sebastián Piñera se convirtió en el primer Presidente de derecha en el Chile postdictadura. Su aprobación fluctuó significativamente, con tendencia a la baja. Cuando las condiciones económicas son favorables, las varianzas en aprobación presidencial se deben a cosas distintas al voto económico. Con modelos logit y probabilidades predichas, basados en encuestas de aprobación presidencial, evaluamos cuatro hipótesis sobre la aprobación de Piñera: un voto de castigo contra la Concertación, un voto económico, la relevancia de prioridades de politicas y el costo de gobernar. Hay evidencia para cada una de ellas. Aunque votar por Piñera puede haber sido una aventura de una noche, los determinantes del voto económico y, en menor medida, la relevancia de prioridades y el costo de gobernar, explican la aprobación de Piñera.

Palabras clave: aprobación presidencial, intención de voto, voto económico, educación, ideología, Chile

We thank the three reviewers for their valuable comments and suggestions. We also thank David Plotke and those attending our presentation in the MPSA 2016 Conference in Chicago and ECPR 2016 conference in Prague. This work was partially financed by Fondecyt Regular \#1172051, CONICYT / FONDAP / 1513009 and by a special grant from the Liberal Studies Program at NYU. 
In January of 2010, after two decades of center-left Concertación governments, Sebastián Piñera (2010-2014) became the first rightwing President of Chile since the end of military rule in 1990 by winning $51.6 \%$ of the vote in the runoff election. Despite favorable economic conditions, his approval ratings began to fluctuate quickly after taking office, falling 20 percentage points from June $2010(48.4 \%)$ to June $2011(28.1 \%)$. By the end of 2011, as the unequal access and high cost of higher education mobilized thousands of students against his government, Piñera reached an unprecedented low in terms of presidential approval in Chile at $23.4 \%$. Although his approval recovered in his last year in office, Piñera had the lowest presidential approval in Chile since 1990.

Piñera's low approval-in the context of a growing economy-has been associated with the student protests and attributed to the alleged punishment of the Concertación (Varas 2014; Morales 2015). However, since presidential approval declined before the student protests, the fluctuations in his approval warrant a more comprehensive explanation. With logit models and predicted probabilities based on pre-electoral and presidential approval polls, we test four hypotheses to explain presidential approval for Piñera: a punishment vote against the Concertación, support tied to economic performance, issue-based support, and the cost of ruling.

Presidents who enjoy high approval in their honeymoons and lose support as their terms progress are a common occurrence in democracies. In countries with low levels of ideological identification, weak party systems, or in nations that experience drastic shifts in economic conditions, presidential approval volatility should not be surprising. However, in countries with institutionalized party systems and economic stability, drastic fluctuations in presidential approval warrant an explanation. In studying Chile, a country with a stable party system and favorable economic conditions at the time of the Piñera administration, we analyze the determinants of rapidly fluctuating downward presidential approval. Presidential approval has fluctuated in Chile since 1990, but no prior president had experienced such a large fluctuation in approval, under favorable economic conditions, as President Piñera. Given Chile's stable multiparty system, with a left and a rightwing coalition, when the economic conditions are stable and favorable, fluctuations in presidential approval cannot be solely explained by economic voting.

In what follows, we discuss the determinants of presidential approval, focusing on economic voting. We also incorporate the possible effect of a punishment vote against the previous government-especially when a new government comes to power after a long tenure by an administration with an opposite ideology. We then discuss the effect of issue salience and cost of ruling on presidential approval. After presenting our four hypotheses-punishment vote against the incumbent coalition, economic vote variables, issue salience and cost of ruling-we examine the context of the 2009-10 presidential election and summarize the main events of Piñera's administration. Using electoral polls and presidential approval polls, we present logistic regression models and 
predicted probabilities to test those hypotheses with regard to the fluctuations in presidential approval for the Piñera administration. We conclude by proposing ways to refine traditional economic vote models for presidential approval.

\section{DETERMINANTS OF PRESIDENTIAL APPROVAL}

Presidential approval can be explained by short, medium or long-term variables. Three major models are each associated with a particular set of variables (Bartels 2011). The Columbia Model, inspired by sociological explanations based on Lipset and Rokkan (1967), explains behavior using long-term variables — cleavages—such as race, social class, religion and other permanent traits, suggesting stable and predictable patterns (Lazarsfeld, Berelson and Gaudet 1944; Lau and Redlawsk 2006). The socialization model uses a socialpsychological approach based on medium-term preferences (Campbell et al. 1960; Converse 1964; Jennings and Niemi 1968; Ventura 2001; Richardson 1991). Voters are politically socialized by parties —or societal organizations-and have stable, but not immutable, preferences. New socialization processes can alter electoral preferences (Bartels 2011). The Columbia and socialization models are less appropriate to account for short-term fluctuations in electoral behavior and presidential approval.

A third model, the Rochester approach, adopts an economic vote, or rational choice approach, based on short-term preferences (Downs 1957; Erikson, MacKuen and Stimpson 2002; Lewis-Beck and Stegmaier 2007; Duch and Stevenson 2008). Economic growth, low inflation and low unemployment benefit the incumbent candidate/party (Erikson, MacKuen and Stimpson 2002; Duggan and Fey, 2005; Duch and Stevenson 2008). Voters attribute to incumbents the responsibility for managing the economy, then judge economic conditions and vote accordingly (Lewis-Beck and Stegmaier 2007). But rationality is not exclusively reduced to economic concerns. When a country undergoes economic stress under a working-class party government, a working class-minded voter is being rational when supporting her party (Knutsen 2007). Yet, most rational choice approaches use economic variables to frame voters' utility functions because, even if at the margin, different elections produce different results. Thus, some pivotal voters respond to short-term variables.

Early economic vote studies used inflation, unemployment, and economic growth to suggest fluctuations in voting behavior (Kramer 1971). Fiorina (1981) and Lewis-Beck (1988) combined economic indicators with institutional variables to account for vote intention and presidential approval. When voters are unsure about which parties are responsible for economic policy-making, it is more difficult for them to punish or reward politicians (Powell and Whitten 1993; Duch and Stevenson 2005). The economic vote is also applied to studies of presidential approval, as approval polls are used as proxies for electoral support (Erikson, MacKuen, and Stimpson 2000, 2002; Canes-Wrone and de 
Marchi 2002; Nadeau et al. 1999; Edwards, 1997). Also following an economic vote logic, Nannestad and Paldam $(1994,1997)$ identified the widely-used VotePopularity (VP) function. Because presidential approval affects vote intention for the incumbent party, presidents will prefer a U-shape approval over a presidential approval pattern that peaks at the middle of the term. Accordingly, presidents will aspire to concentrate their efforts in affecting approval at the beginning and end of their terms, when there is more at stake. When the outgoing president or government are unpopular, opposition candidates might benefit from a so-called punishment vote against the incumbent coalition (Ferejohn 1986). After several consecutive terms in power, a ruling coalition is more likely to suffer from such a punishment vote (Kim and Wang 2003). Thus, economic vote variables can be complemented with information on how voters assess the outgoing government and how likely they are to punish or reward incumbent parties or coalitions on voting day.

Although economic vote models allow for fluctuations in presidential approval, when economic conditions and perceptions are stable, there not should be significant fluctuation in presidential approval. Yet, in discussing presidential approval volatility, Kriner and Schwartz (2009: 609) argue that "developments that conflict with a group's partisan predispositions increase the volatility of approval." Those developments affect groups differently. Hardliners should more immune to those shocks while swing supporters will show higher presidential approval volatility under those circumstances. Moreover, in an emerging democracy undergoing its first alternation in power-such as Chile in 2010 - the effect of economic vote variables on presidential approval might be distorted by the experience of having the former opposition in power for the first time.

Presidential approval is also affected by the policies that governments implement. The salience of issues has been found to influence presidential approval (Ostrom et al. 2017). Latent issues become salient when governments implement policies that might polarize the electorate or when political developments lead the government to defend positions that might be unpopular with the electorate. When the salience of issues puts the government at odds with part of the electorate, there is a negative effect on presidential approval. Conversely, when the government adopts popular priorities, presidential approval might increase even if economic conditions are unfavorable (Ostrom et al. 2017). Thus, the salience of issues might have a mitigating effect on the importance of economic vote variables when it comes to presidential approval.

In addition, presidential approval might be affected by the wear-and-tear of the act of governing, a phenomenon that has come to be known as the cost of ruling. This cost is incurred as people react to government policies and their outcomes (Paldam 1986). Under favorable international economic and political conditions, governments will benefit from a tailwind effect. After a long tenure by a government of a certain ideology, a new government of a different ideological inclination might experience an additional popularity bump in the 
honeymoon period. Later on, disappointment might be generated as electoral promises take time to materialize and people perceive that the new government reproduces some of the unpopular practices or features of the old government. The cost of ruling effect could be especially relevant when the new government represents a party that has never been in power, or that returns to power after a long tenure by an ideologically-opposite party.

In Latin America, economic crises have undermined support for incumbents and induced electoral volatility (Remmer 1991). Roberts and Wibbels (1999) found pro-incumbent vote shifts. Stokes et al. (2001) analyzed public support for economic reforms in the 1990s, stressing the importance of economic performance. In countries with low party system institutionalization, Gélineau (2007) found that institutional characteristics constrain the ability of voters to hold the incumbent party responsible for economic performance. Analyzing polls from 12 countries, Lewis-Beck and Ratto (2013: 489) showed that "governments are rewarded or punished according to the economic performance they command." Carlin and Singer (2015) qualify the usefulness of the economic vote according to particular traits and conditions in different Latin American countries. Presidential approval for the outgoing president helps explain vote intention for the incumbent party candidate in Mexico (Romero 2009). The effect of economic performance on presidential approval has also been reported for Argentina (Remmer and Gélineau 2003; Cataife 2011), Venezuela (Weyland 1998) and Peru (Weyland 2000; Arce 2003; Morgan 2003; Arce and Carrión 2010). Economic perceptions have also been found to influence democratic consolidation, political culture, democratic legitimacy and trust in institutions (Hawkins et al. 2008; Luna 2008; Morales 2008; Segovia et al. 2008; Booth and Seligson 2009; Córdova and Seligson 2010; Seligson and Smith 2010).

In Chile, economic variables have also been used to explain presidential approval (Morales 2008; Cabezas and Navia 2010; Perelló 2015) even during the transition to democracy (Panzer and Paredes 1991). Yet, until 2010, Chile had only experienced center-left Concertación governments. Piñera was the first right-of-center, democratically elected president since the transition. Since support for Piñera fell after he took office, under positive economic conditions-5.3\% GDP growth, 3.8\% inflation and 6.9\% unemployment between 2010 and 2014 - the economic vote alone is insufficient to explain fluctuations in presidential approval. Although he was not the first Chilean president to suffer from declining approval, Piñera was the first to experience such a decline under favorable economic conditions-thus calling into question economic vote explanations.

To explain Piñera's fluctuating presidential approval, we must first review the explanations for his victory. Declining turnout, with slightly over half eligible voters casting ballots, and with even lower turnout among the youth, weakened the effect of the authoritarian-democratic cleavage that influenced elections in the 1990s (Contreras and Navia 2013; Luna and Toro Maureira 2010). As a result, Piñera had an opportunity to build a stronger base for rightwing parties 
attracting moderate voters. Piñera's victory might have been partially caused by discontent with the Concertación. Yet, depending on the government policies he would set out to implement, Piñera could induce a new alignment in the electorate. Pointing to self-inflicted wounds, Navia and Morales (2010) imply that, despite his clever campaign strategy and efforts to reinvent the right, Piñera would not have won had the Concertación avoided mistakes in the candidate nomination process. Elacqua and Aninat (2013) argue that pragmatic middle-class voters abandoned the Concertación in 2009 because Frei put too much emphasis on state solutions.

High presidential approval volatility under Piñera might point to swing voters who abandoned him after electing him. Hence, models that predict stable electorates or those that associate shifts in approval with changing economic conditions might be insufficient to explain presidential approval volatility in Chile. We consider the extent to which economic vote variables explain presidential approval in Chile. Yet, since elections were consistently favorable to the Concertación between 1989 and 2005, we test whether Piñera's victory was simply the result of a punishment vote against the incumbent coalition. However, since the 2011 student protests were also a defining moment for Piñera's presidency, we test for the effect of issue salience on approval, and for the possible effect of a cost of ruling variable. Thus, we formally propose four hypotheses:

H1: As Piñera's victory is partially explained by a punishment vote against the Concertación, the determinants of his vote intention and presidential approval should be different.

H2: Economic vote variables explain presidential approval for Piñera.

H3: Issue salience explains presidential approval for Piñera.

H4: The cost of ruling explains presidential approval for Piñera.

The case of Chile allows us to better understand the evolution of presidential approval in democracies that have been governed by the same party or coalition for a long time before experiencing an alternation in power. Although cases where alternation in power after a long tenure by the same coalition are common, there are far fewer cases where that alternation occurred in the context of an expanding economy. In the absence of an economic crisis, alternations in power after a long tenure by the same coalition offer a unique opportunity to understand the dynamics of presidential approval determinants.

\section{DATA AND METHODOLOGY}

We use polling data from the highly regarded Centro de Estudios Públicos (CEP). We analyze the longitudinal evolution of presidential approval in the nine polls conducted under Piñera's term. We also include a pre-electoral poll conducted 
in October 2009 that asked about vote intention in the first round and in a hypothetical runoff between Piñera and Frei. We use that pre-electoral poll to compare electoral support for Piñera with his initial presidential approval. We use binomial logistic regression models and change in predicted probabilities to identify the determinants of support for Piñera.

The dependent variable is presidential approval-although we also use vote intention for the pre-electoral poll as a point of comparison with the first presidential approval numbers. The variable takes the value of 1 if the respondent approves of Piñera as president. Our models also include long-term variables. Sex is coded as 1 for women. Age is a continuous variable. Capital takes the value of 1 for respondents who live in the capital city, and 0 for those who reside elsewhere in the country. Socioeconomic status is a continuous variable ( $0=$ Low $/ 0.5=$ Middle/1=High). Ideology divides respondents into those who self-identify with the right, center and left, and those who do not identify on the ideological scale (the reference category). Our short-term variables include sociotropic, ${ }^{1}$ sociotropic prospective, ${ }^{2}$ egotripoc ${ }^{3}$ and egotropic prospective $e^{4}$ outlook. Each variable is continuous $(0=$ Negative outlook $/ 0.5=$ Neutral $/ 1=$ Positive). CEP polls ask respondents about their top three priorities for government action. ${ }^{5}$ We created dummy variables for education, jobs, security and healthsince people mention three priorities, the totals add up to $300 \%$, not $100 \%$.

Formulas 1 and 2 summarize the aggregate regression model and Table 3 provides a summary of statistics. ${ }^{6}$

Approval $=f($ socio - demographics, ideology, economic outlook, salient issues $)$

$$
\begin{aligned}
\text { Approval }= & \beta_{0}+\beta_{1} \text { Sex }+\beta_{2} \text { Age }+\beta_{3} \text { SES }+\beta_{4} \text { Capital }+\beta_{5} \text { Ideology }+\beta_{6} \text { Sociotropic } \\
& +\beta_{7} \text { Sociotropic prospective }+\beta_{8} \text { Egotropic }+\beta_{9} \text { Egotropic prospective } \\
& +\beta_{10} \text { Education }+\beta_{11} \text { Jobs }+\beta_{12} \text { Security }+\beta_{13} \text { Health }+\varepsilon
\end{aligned}
$$

1 The question is, "De acuerdo a esta escala, ¿Cómo calificaría Ud. la actual situación económica del país?" (According to this scale, how would you rate the current economic situation of the country?) The alternatives are (1) Very bad, (2) Bad, (3) Neither good or bad, (4) Good, and (5) Very good.

2 The question is “ ¿Ud. piensa que en los próximos 12 meses la situación económica del país mejorará, no cambiará o empeorará?" (Do you think that in the next 12 months the economic situation of the country will improve, not change or worsen?) The alternatives are (1) It will improve, (2) It won't change, and (3) It will worsen.

3 The question is, "De acuerdo a esta escala, ¿Cómo calificaría Ud. Su actual situación económica?" (According to this scale, how would you rate YOUR current economic situation?) The alternatives are (1) Very bad, (2) Bad, (3) Neither good or bad, (4) Good, and (5) Very good.

4 The question is, "En los próximos 12 meses, ¿cómo cree Ud. que será SU situación económica?" (In the next 12 months, how do you think YOUR economic situation will be like?) The alternatives are (1) Much better, (2) Better, (3) Same, (4) Worse, and (5) Much worse.

5 The question is, “¿Cuáles son los tres problemas a los que debería dedicar el mayor esfuerzo en solucionar el gobierno? Indique sólo 3. (What are the three problems that the government should be devoted to solving? Mention only 3).

6 For the first hypothesis, we compare vote intention with presidential approval and thus our dependent variables of interest are both "vote" and "approval" 
Table 1. Summary Statistics of Dependent and Independent Variable

\begin{tabular}{lccccc}
\hline \multicolumn{1}{c}{ Variable } & $N$ & $\overline{\mathrm{x}}$ & $s$ & Min & Max \\
\hline Vote in First Round & 1,264 & 0.36 & 0.48 & 0 & 1 \\
Vote in Runoff & 1,264 & 0.44 & 0.50 & 0 & 1 \\
Approval & 12,326 & 0.32 & 0.46 & 0 & 1 \\
Sex & 13,590 & 0.59 & 0.49 & 0 & 1 \\
Age & 13,590 & 0.47 & 0.18 & 0.18 & 0.99 \\
Socioeconomic status & 13,590 & 0.42 & 0.21 & 0 & 1 \\
Capital & 13,590 & 0.37 & 0.48 & 0 & 1 \\
Ideology & 13,590 & 1.04 & 1.21 & 0 & 3 \\
Sociotropic & 13,590 & 0.46 & 0.21 & 0 & 1 \\
Sociotropic prospective & 13,590 & 0.59 & 0.31 & 0 & 1 \\
Egotropic & 13,590 & 0.49 & 0.19 & 0 & 1 \\
Egotropid prospective & 13,590 & 0.59 & 0.18 & 0 & 1 \\
Education & 13,590 & 0.41 & 0.49 & 0 & 1 \\
Jobs & 13,590 & 0.25 & 0.43 & 0 & 1 \\
Security & 13,590 & 0.50 & 0.50 & 0 & 1 \\
Health & 13,590 & 0.42 & 0.49 & 0 & 1 \\
\hline
\end{tabular}

Source: Authors, based on CEP Surveys (www.cepchile.cl)

\section{PRESIDENTIAL ELECTIONS IN CHILE, 1989-2013}

Since the transition to democracy in 1989, presidential elections in Chile have reflected the multi-party system organized around two coalitions. After a democratic/authoritarian divide defined the transition to democracy, prodemocracy parties formed the Concertación, a coalition comprised of centrist and leftist parties. On the right, the Alianza, comprised of Renovación Nacional (RN) and Unión Demócrata Independiente (UDI), grouped those who supported Pinochet. Figure 1 shows presidential election results from 1989 to 2009. After badly losing in 1989 and 1993, the Alianza forced a runoff in 1999, when the country was undergoing an economic recession. Yet, the Concertación prevailed for a third consecutive presidential election victory. In 2005, the combined vote for the two Alianza candidates, Sebastián Piñera (RN) and Joaquín Lavín (UDI), was higher than the Concertación's for the first time since 1989. Yet, in the runoff, the Concertación's Michelle Bachelet defeated Piñera, although the latter became the frontrunner for 2009. Between 1989 and 2005/06, the Concertación consistently won presidential elections despite the fact that rightwing candidates became increasingly more competitive. 
Figure 1. Presidential election results in Chile, 1989-2010*

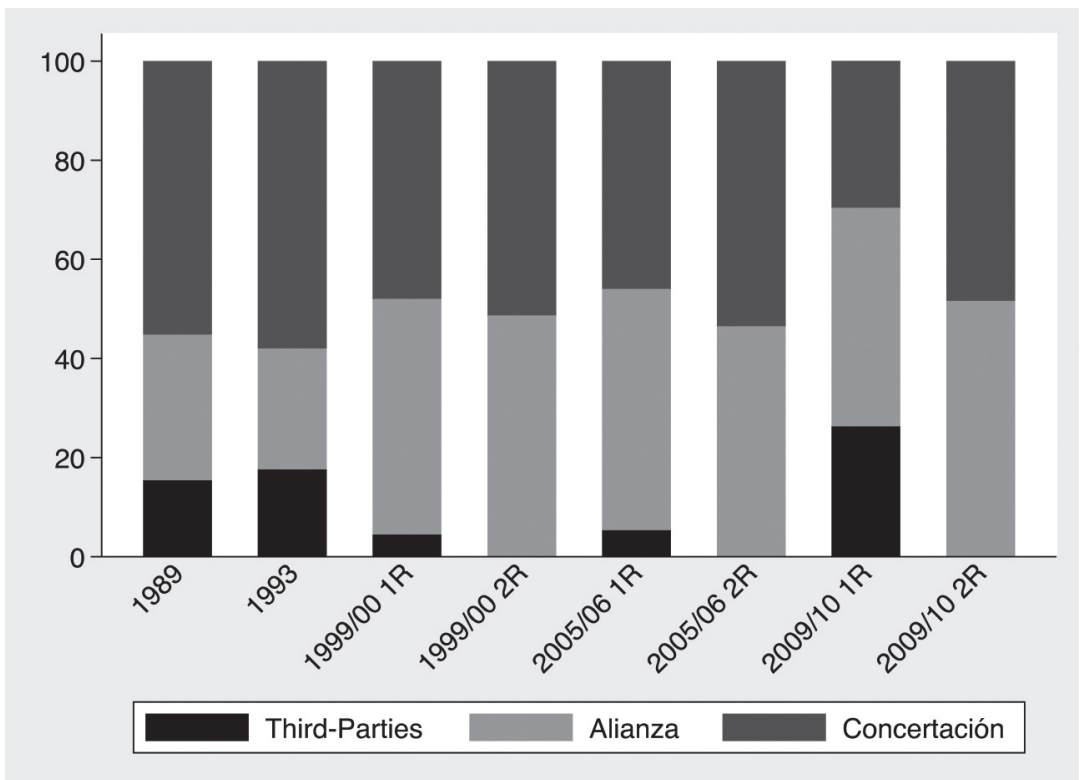

*Vote share of third-party candidates includes all non-Concertación or Alianza candidates: Francisco Errázuriz (15.4\%) in 1989; José Piñera (6.2\%), Manfred Max Neef (5.6\%), Eugenio Pizarro (4.7\%) and Cristián Reitze (1.2\%) in 1993; Gladys Marín (3.2\%), Tomás Hirsch (0.5\%), Sara Larraín (0.4\%) and Arturo Frei Bolívar (0.4\%) in 1999; Tomás Hirsch (5.4\%) in 2005, Marco Enríquez-Ominami (20.1\%) and Jorge Arrate (6.2\%) in 2009. For the Alianza in 2005, we combined the vote share of Piñera (25.4\%) and Lavín (23.2\%).

Source: Authors, based on Servicio Electoral de Chile (https://www.servel.cl/)

In 2009, there were 4 presidential candidates. Piñera was the sole rightwing candidate. He faced a weakened and splintered left. Former president Eduardo Frei (1994-2000), a moderate Christian Democrat (PDC), was the Concertación candidate. The Communist Party's Juntos Podemos Más coalition recruited Jorge Arrate, a former minister and Socialist Party (PS) member, as its candidate. Another former PS member, rogue legislator Marco Enríquez-Ominami (MEO), also ran as an independent. The presence of two leftwing alternative presidential candidates reflected the weakening of the center-left coalition. Yet, because the authoritarian-democratic divide was still relevant, many expected all leftwing forces to coalesce around a single candidate-presumably Frei-in the runoff, as had happened in 1999/00 and 2005/06. Consequently, Piñera ran a campaign highlighting his moderation and his opposition to Pinochet in the 1988 plebiscite, appealing to the median voter that had grown tired of 20 years of consecutive Concertación governments.

The economic crisis of 2008/09 caused Chile's first recession in 10-years. Even though outgoing President Bachelet reached record-breaking approval, support for the Concertación declined to an all-time low. In the 2008 municipal election, the Alianza obtained its first victory in such contests since they were first held in 1992. In 2009, the Concertación further alienated many supporters when it rejected open primaries to select its presidential candidate. The decision led 
ME-O to run as an independent. Thus, several other reasons might explain the Concertación's electoral vulnerability: the weaning after 20 years in power, unfavorable economic conditions, a divisive presidential nomination process, and a unified opposition. As Table 2 shows, Piñera had a plurality in the firstround vote and won the runoff by a slim margin.

Table 2. Presidential Election Results, 2009/2010

\begin{tabular}{lrrrc}
\hline \multicolumn{1}{c}{ Candidate } & First round vote & \multicolumn{1}{c}{$\%$} & Runoff vote & \multicolumn{1}{c}{$\%$} \\
\hline Sebastián Piñera & 3.074 .174 & 44.1 & 3.591 .182 & 51.6 \\
Eduardo Frei & 2.065 .061 & 29.6 & 3.367 .790 & 48.4 \\
Marco Enríquez-Ominami & 1.405 .124 & 20.1 & & \\
Jorge Arrate & 433.195 & 6.2 & & \\
\hline Valid Votes Total & 6.977 .544 & 100 & 6.958 .972 & 100 \\
\hline Null and Blank votes & 286.592 & & 244.399 & \\
Turnout total & 7.264 .136 & & 7.203 .371 & \\
Voting age population & 12.277 .915 & & 12.277 .915 & \\
(VAP) & & 56.8 & & 56.7 \\
Valid votes as \% of VAP & & & & \\
\hline
\end{tabular}

Source: Authors, based on Servicio Electoral de Chile (https://www.servel.cl/)

Based on CEP polls from 2009, Table 3 shows that Piñera had strong support from rightwing and upper-class voters, two traditional Alianza support groups. Piñera also did well among the youth. In the runoff, Frei did slightly better among older Chileans - those most likely to be influenced by the authoritariandemocratic divide. Piñera won in every other age group, while his support was strongest among those aged 34 and younger. Piñera also gained support among the middle class - another traditional Concertación voting bloc. Frei only won among lower-income groups. Piñera also led among Chileans who did not identify with the left-to-right ideological spectrum. In the runoff, $42 \%$ of those who did not identify with the left-right the political scale planned on voting for Piñera. The rightwing candidate also benefited from the Concertación's infighting. Although Arrate voters were more loyal to the Concertación, one of every three ME-O voters in the first round went for Piñera in the runoff. 
Table 3. Vote Intention for Frei and Piñera by Selected Indicators, October 2009 $(\%)^{*}$

\begin{tabular}{|c|c|c|c|c|c|}
\hline \multirow{2}{*}{\multicolumn{2}{|c|}{ Variables }} & \multicolumn{2}{|c|}{ Frei } & \multicolumn{2}{|c|}{ Piñera } \\
\hline & & First round & Runoff & First round & Runoff \\
\hline \multirow{2}{*}{ Sex } & Men & 23.9 & 35.4 & 39.3 & 46.0 \\
\hline & Women & 23.9 & 37.6 & 32.1 & 41.8 \\
\hline \multirow{4}{*}{ Age } & $18-24$ & 16.7 & 37.2 & 35.2 & 46.8 \\
\hline & $25-34$ & 16.5 & 30.3 & 41.1 & 51.6 \\
\hline & $35-54$ & 26.8 & 38.3 & 34.9 & 42.5 \\
\hline & $55+$ & 30.5 & 38.3 & 32.5 & 37.4 \\
\hline \multirow{2}{*}{ Capital } & Santiago & 18.1 & 31.8 & 36.8 & 47.3 \\
\hline & Others & 28.0 & 39.8 & 34.7 & 41.4 \\
\hline \multirow{3}{*}{$\begin{array}{l}\text { Socioeconomic } \\
\text { status }\end{array}$} & High & 12.0 & 21.2 & 59.7 & 62.9 \\
\hline & Middle & 17.7 & 31.9 & 37.6 & 46.9 \\
\hline & Low & 31.7 & 43.0 & 30.8 & 38.5 \\
\hline \multirow{4}{*}{ Ideology } & Right & 9.0 & 15.0 & 76.4 & 79.4 \\
\hline & Center & 33.4 & 45.9 & 30.2 & 43.0 \\
\hline & Left & 38.9 & 64.3 & 10.9 & 16.8 \\
\hline & None & 19.8 & 29.0 & 31.6 & 42.0 \\
\hline \multicolumn{2}{|c|}{$N(\%)$} & $377(25.1 \%)$ & $556(37 \%)$ & $526(35 \%)$ & $643(42.7 \%)$ \\
\hline \multicolumn{2}{|c|}{$\begin{array}{l}\text { ME-O First-round voters } \\
(N=309,22.1 \%)^{* *}\end{array}$} & & $40 \%$ & & $32.6 \%$ \\
\hline \multicolumn{2}{|c|}{$\begin{array}{l}\text { Arrate First-round voters } \\
(N=61,4.2 \%)^{* *}\end{array}$} & & $59 \%$ & & $17.4 \%$ \\
\hline
\end{tabular}

* Total sample. Does not include Null/Blank responses.

**Vote intention for Marco Enríquez-Ominami (ME-O) and Jorge Arrate.

Source: Authors, based on CEP Survey \# 61 (www.cepchile.cl)

\section{PRESIDENTIAL APPROVAL IN CHILE, 1989-2013}

Figure 2 shows approval for Concertación Presidents Patricio Aylwin (19901994), Eduardo Frei (1994-2000), Ricardo Lagos (2000-2006), Michelle Bachelet (2006-2010), as well as Alianza President Sebastián Piñera (2010-2014). Ever since the transition to democracy, presidents have enjoyed honeymoons and have experienced subsequent fluctuations in support. Piñera was the first one to see his job approval decline so rapidly after taking office.

Piñera's approval remained in the high-40s in his first year as president. In his second year, as student protests emerged and intensified, Piñera's approval fell 
to $28 \%$ in mid-2011 and $23 \%$ in December 2011. Towards the second-half of his presidency, Piñera's approval improved, averaging 28\% in 2012 and 34\% in 2013. Yet, his approval ratings never fully recovered to pre-2011 levels. Piñera experienced a significant drop in approval more rapidly than his predecessors and was more unpopular than popular throughout most of his presidency.

Figure 2. Presidential approval in Chile, 1990-2013

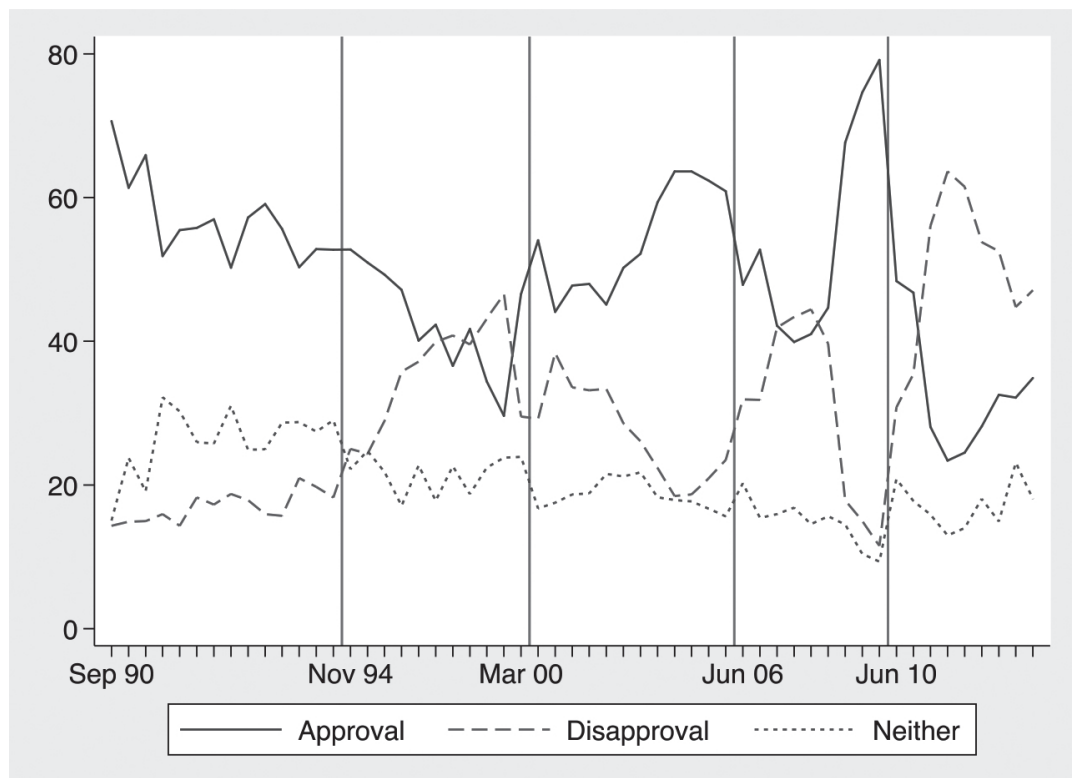

\footnotetext{
* The vertical lines separate the presidencies of Patricio Aylwin (1990-1994), Eduardo Frei (1994-2000), Ricardo Lagos (2000-2006), Michelle Bachelet (2006-2010) and Sebastián Piñera (2010-2014).

Source: Authors, based on CEP Surveys (www.cepchile.cl)
}

Piñera's job approval declined even as the economy expanded. Influenced by the 2008/09 international financial crisis, Chile entered into a recession in 2009. GDP per capita declined by $2.5 \%$ and unemployment reached doubledigit figures. The country's economy began recovering in 2010, just as Piñera started his 4-year presidency. By late 2010, GDP per capita growth was 4.8\% and unemployment fell to $8.4 \%$. The economy continued preforming well throughout Piñera's presidency. Figure 3 shows selected macroeconomic indicators dating back to 1990. From 2010 to 2013, GDP per capita growth averaged $4.3 \%$. Unemployment reached an almost two-decade low of $6.2 \%$ in 2013. Inflation remained low. Overall economic conditions were better under Piñera than under his two predecessors, Bachelet and Lagos. Yet, Piñera's approval on average was lower than that of either Lagos or Bachelet. 
Figure 3. Economic indicators in Chile, 1990-2014*

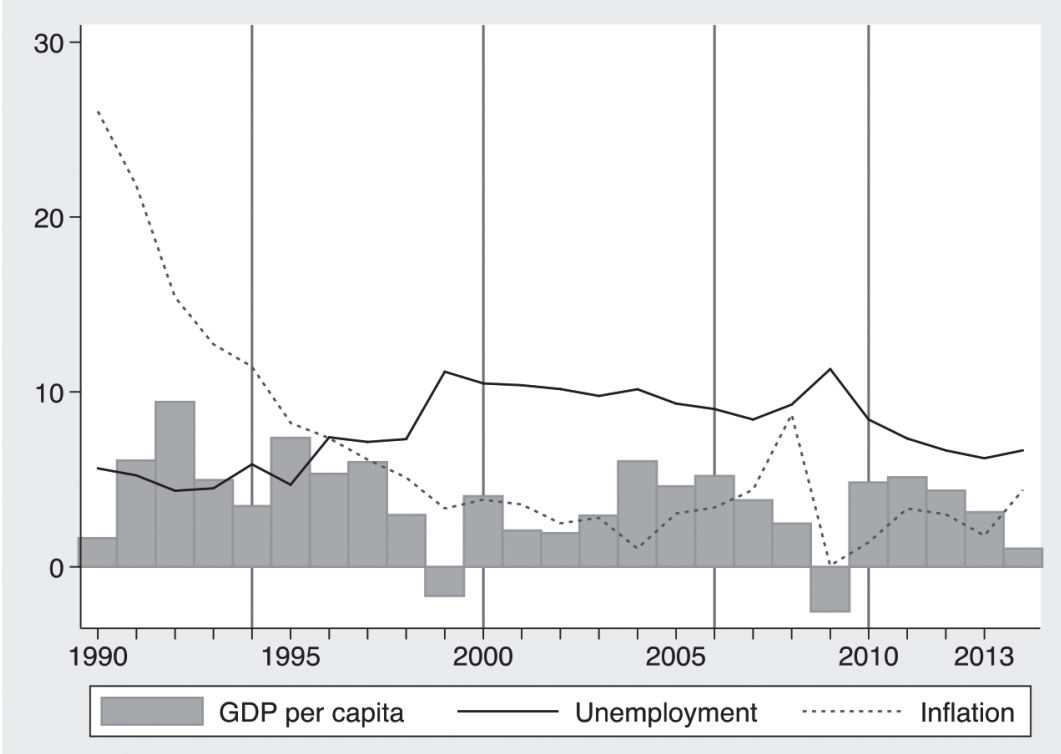

* The vertical lines separate the presidencies of Patricio Aylwin (1990-1994), Eduardo Frei (1994-2000), Ricardo Lagos (2000-2006), Michelle Bachelet (2006-2010) and Sebastián Piñera (2010-2014).

Source: Authors, based on the World Bank (https:/ / data.worldbank.org)

Since the country's economy was performing well, it seems unlikely that Chileans punished Piñera solely because of the government's handling of the economy. Figure 4 shows the evolution in vote intention and presidential approval for Piñera (2009-2013) and the evolution in economic outlook perceptions in CEP polls. There was variance in egotropic and sociotropic views, present and prospective, under the Piñera presidency. A majority of Chileans had neutral views on the economy during most of Piñera's presidency. This occurred despite the economic recovery starting in 2010. Prospective socio and egotropic views were more optimistic in the pre-electoral poll of 2009. After the election, neutral economic assessments prevailed over positive and negatives views from mid2010 to late 2013.

Positive and negative assessments fluctuate with Piñera's approval. There is an inverse relationship between presidential approval and negative economic outlook. As Piñera's approval declined, negative sociotropic and egotropic assessments increased. As presidential approval improved, so did positive sociotropic and egotropic assessments. Despite the positive trend in economic indicators, people's views on the economy fluctuated in different directions throughout the term, with differences in egotropic and sociotropic current and prospective positive and negative outlooks. 
Figure 4. Presidential Approval and Economic Outlook in Chile, 2009-2013*
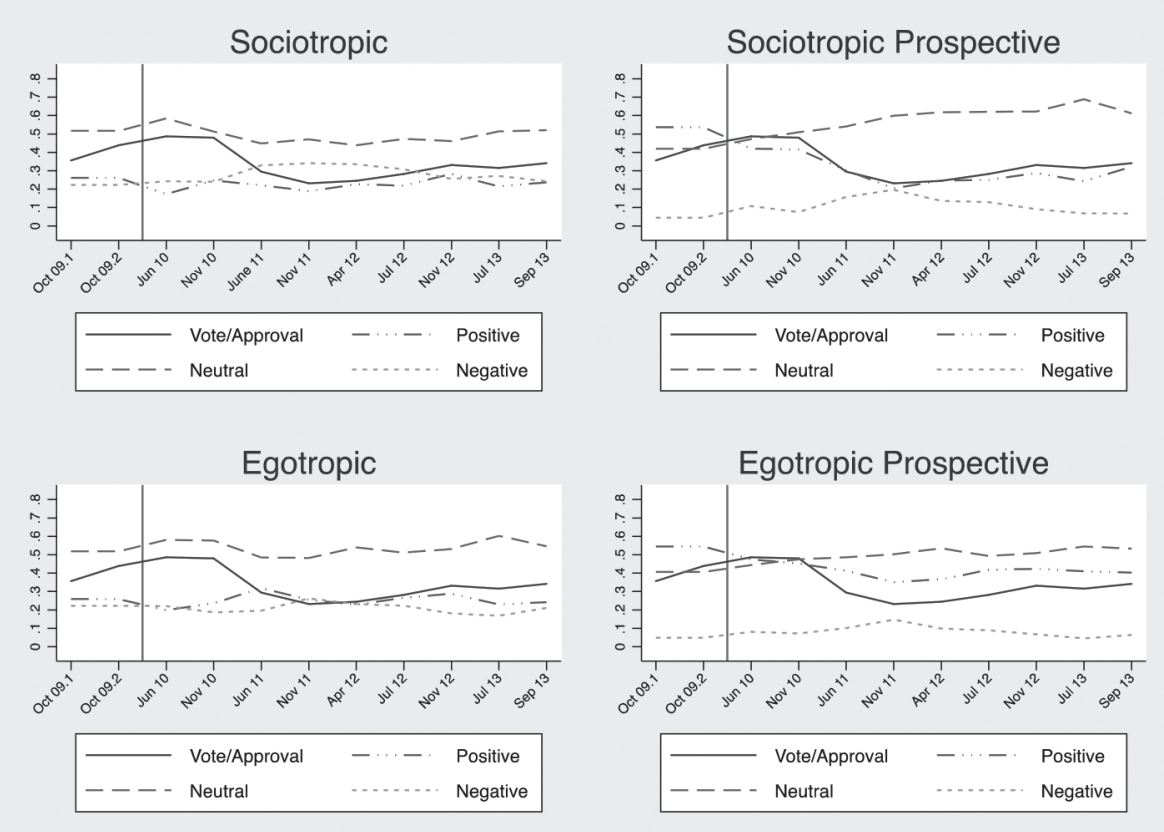

* The vertical line divides the pre-electoral (October 2009) from the post-electoral polls (June 2010, November 2010, June 2011, November 2011, April 2012, July 2012, November 2012, July 2013 and September 2013). The first shows vote intention for then candidate Piñera. The remaining 9 polls show job approval for president Piñera. Source: Authors, based on CEP Surveys (www.cepchile.cl)

Given that we are assessing the effect of issue salience and cost of ruling, we include relevant indicators to measure the extent to which issue salience and cost of ruling affected approval. CEP polls also ask respondents to enumerate the three problems that the government should be devoted to solving. Figure 5 shows presidential approval and the percentage of respondents who mention public security, jobs, education and health as priorities the government should focus on. Public security is a constant concern, being the most mentioned in the 2009 election year and during Piñera's presidency. Security as a priority for government action peaked as Piñera's job approval reached the lowest point in his presidency. Concerns with jobs experienced a decline after the presidential elections and then fluctuated similarly with presidential approval. Education fluctuated inversely with Piñera's job approval in the first two years, after which concern with education and Piñera's approval converged. Popular concern with health increased, especially towards the end of the term, moving together with presidential approval in the second half of the administration.

Although some of the popular priorities for government moved together with Piñera's approval and others moved opposite to Piñera's approval, no single priority can directly account for the fluctuations in Piñera's presidential 
approval-and especially in the rapid decline in presidential approval observed in the first year of his administration. However, there is visual evidence that as people's priorities differed from those of the government, Piñera's approval was negatively affected.

Figure 5. Presidential Approval Issue Salience in Public Opinion Polls in Chile, 2009-2013*
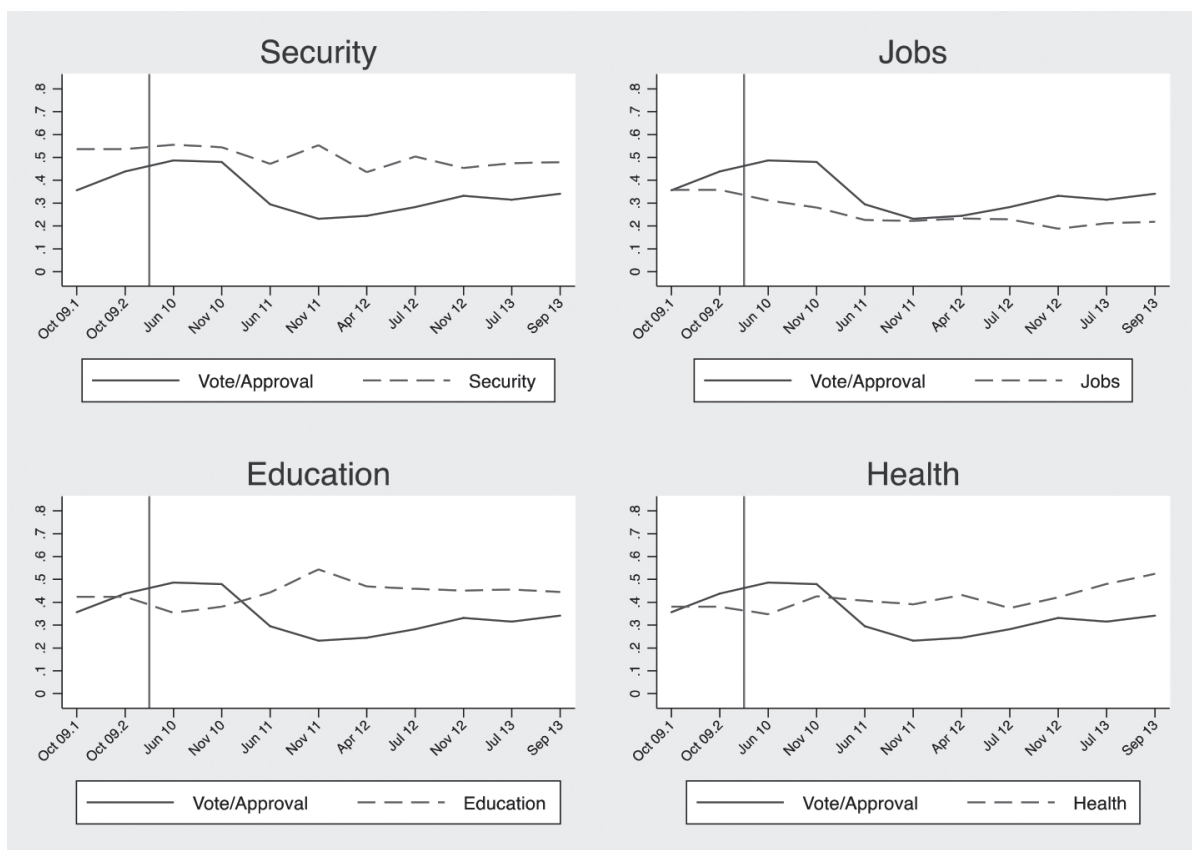

* The vertical line divides the pre-electoral (October 2009) from the post-electoral polls (June 2010, November 2010, June 2011, November 2011, April 2012, July 2012, November 2012, July 2013 and September 2013). The first shows vote intention for then candidate Piñera. The remaining 9 polls show job approval for president Piñera. Source: Authors, based on CEP Surveys (www.cepchile.cl)

Presidential approval for Piñera fell faster than for any other previous Chilean president. His honeymoon was shorter even though the economy was on a solid recovery. While the economy was growing throughout much of Piñera's presidency, polls reported fluctuations in people's positive and negative current and prospective assessments. With the exception of security, popular priorities for government action fluctuated under Piñera in directions that do not directly coincide with Piñera's approval. In the next section, to test our four hypotheses, we run a series of binomial logistic regression models and report change in predicted probabilities to examine the determinants of support for Piñera. 


\section{INFERENTIAL ANALYSIS}

We use binomial logit regressions to determine support for President Piñera. Table 4 shows the log-odds and Table 5 shows the change in predicted probabilities. Our dependent variable of interest is presidential approvalalthough we also report vote intention in the first-round and runoff for Piñera in the 2009 poll to compare the determinants of vote intention with those of presidential approval to assess the effect of a possible punishment vote.

Our independent variables can be grouped into three sets of predictors. The first are long term predictors, including socio demographic (sex, age, region of residence and socioeconomic status) and ideological variables (selfidentification on the ideological scale). Then, we present the effect of economic vote variables (present and retrospective sociotropic and egotropic outlook). Third, we include a set of dummy variables to identify issue salience and cost of ruling. We identify those people who mention education, jobs, security and health as priorities for government action.

To test our first hypothesis, we include two models that predict vote intention for Piñera in the first-round and runoff elections in 2009. In the first-round, but not in the runoff, women were less likely than men to vote for Piñera. Age did not have a significant effect in the first-round. But in the runoff, younger voters supported Piñera more strongly. Vote intention for Piñera increased with socioeconomic status (SES). Not surprisingly, rightwing respondents were more likely to support Piñera. Leftwing voters were less likely to vote for Piñera, and those identified with the center were not statistically different than the nonidentified group in the first round.

Sociotropic variables were more robust predictors in explaining electoral support for Piñera than egotropic assessments. Respondents with a positive sociotropic view were less likely to support Piñera in the runoff, while those with a positive sociotropic prospective outlook were more likely to vote for him in both rounds. Only respondents with a positive egotropic outlook were less likely to vote for Piñera in the first-round. Concern with jobs and security increases the likelihood of voting for Piñera. In sum, Piñera's core electoral constituencies were middle and high SES groups who identified with the right and prioritized security and jobs. Piñera's voters also tended to have a more pessimistic sociotropic and egotropic economic outlook, as well as a postivie sociotropic prospective outlook - thus pointing to a punishment vote against the incumbent Concertación government.

Our dependent variable for the other three hypotheses is presidential approval. Table 4 presents models of Piñera's approval by year, aggregating the corresponding CEP polls. Sex is never a significant determinant of support for Piñera. Being older increases the likelihood of approving of Piñera in 2011 and 2012. A higher SES increases the likelihood of approving Piñera in 2011 and 2013. In 2010, Santiago residents were less likely to approve of Piñera than 
those who resided elsewhere. Ideology remains a strong predictor. Rightwing respondents were always more likely to approve of Piñera than those who did not self-identify on the left-right scale. Leftwing respondents were the least supportive. Interestingly, being centrist positively explains presidential approval in 2010, 2012 and 2013.

The economic vote variables show that respondents with a positive current sociotropic and prospective sociotropic outlooks were more likely to approve of Piñera. A positive current egotropic outlook had a strong and positive effect on approving Piñera in 2011 and 2012. Similarly, a positive prospective egotropic outlook held a positive effect on presidential approval throughout Piñera's presidency. Prospective economic vote variables lose statistical significance during the last year of Piñera's government-an outcome we attribute to the presidential contest of 2013, as people's prospective views might have been informed by their expectations of who would win the next election.

The policy variables show how public priorities for government action varied in their effect on Piñera's approval. Education negatively accounts for presidential support. However, the variable is only significant in 2011, when the studentled protests peaked. Our model shows no statistically significant differences in the priority the government should have towards education in the first and last two years of Piñera's presidency. Those who prioritized jobs were also less likely to approve of the president in the last two years. There are no statistically significant differences in prioritizing security and approving or disapproving of Piñera. Interestingly, prioritizing health as a government policy increased the likelihood of approving of Piñera in the first and last year.

In the full model, older respondents, those with higher SES, those living outside the capital, rightwing and centrist voters, and those with current and prospective sociotropioc and prospective egotropic views were more likely to approve of Piñera. Leftists were more likely to reject his performance. In terms of issue salience, those who prioritized education and jobs as a policy for government action were more likely to disapprove of his presidency, while those who prioritized security were more likely to approve of him.

There are three main takeaways from our models. First, economic outlook had a significant effect on Piñera's approval ratings. Piñera's support was positively explained by present and prospective sociotropic and egotropic assessments, Yet, the effect is weaker for present egotropic outlook. Thus, there is evidence that supports the economic vote hypotheses. Those with more optimistic views were more likely to approve of President Piñera-although the effect of economic vote variables was weaker than the effect of self-identification on the left-right scale. A higher SES also had a positive effect on presidential approval, but its effect was weaker than the effect of economic vote variables.

Second, the models reveal a limited issue salience effect on Piñera's approval. Education as a priority for government action-a variable that could be 
expected to have negatively impacted Piñera's approval in the wake of the student protests - had a limited negative effect on his overall approval. It is only significant in 2011, the year student-led protests peaked, and in the full model. Perceiving jobs as a priority holds a negative effect on presidential approval in 2012 and 2013, two years when the unemployment rate was low, and in the full model. That might point to a cost of ruling effect, as those who prioritized jobs punished the government in the latter part of the administration when they failed to see progress on the issue they cared about. This is reinforced by the fact that those who prioritized jobs were more likely to vote for Piñera in the firstround vote in 2009 . There was no statistically significant difference in prioritizing security and approving of Piñera in the annual models, but prioritizing security has a positive effect on approving of Piñera in the full model. Prioritizing health had a positive effect on presidential approval in Piñera's first and last years in office, but not in the full model. Thus, there is partial evidence that issue salience had an effect on presidential approval under Piñera, and that the cost of ruling also affected presidential approval.

Third, the model reveals changes in the determinants of electoral support for Piñera and for presidential approval. Piñera's core electoral constituencies were women from middle and high SES groups who identified with the right, had negative egotropic assessments and a positive prospective sociotopic outlook, and who also prioritized security and jobs. President Piñera's core supporters (2010-2013) were older respondents from middle and high SES backgrounds, lived outside Santiago and identified mostly with the right and to a lesser extent with the center. They were also more likely to have positive sociotropic current and prospective assessments and egotropic prospective assessments. Prioritizing education and jobs made people less likely to approve of Piñera while security made people more likely to approve of Piñera. Since the determinants of electoral support and presidential approval change, we conclude that there is evidence in support of the hypothesis that suggests some initial support for Piñera was intended as a punishment vote against the incumbent administration. 
Table 4. Binomial Logit Regression Model for Vote Intention and Presidential Approval

\begin{tabular}{|c|c|c|c|c|c|c|c|}
\hline \multirow{2}{*}{ Variables } & \multicolumn{2}{|c|}{ Vote Intention } & \multicolumn{5}{|c|}{ Presidential Approval } \\
\hline & 1R 2009 & 2R 2009 & 2010 & 2011 & 2012 & 2013 & Full Model \\
\hline \multirow[t]{2}{*}{ Sex } & $-0.303^{* *}$ & -0.201 & 0.149 & -0.138 & -0.0580 & 0.185 & 0.0362 \\
\hline & $(0.143)$ & $(0.135)$ & $(0.137)$ & $(0.166)$ & $(0.110)$ & $(0.140)$ & $(0.0692)$ \\
\hline \multirow[t]{2}{*}{ Age } & -0.0500 & $-0.867^{* *}$ & 0.139 & $1.004^{*}$ & $1.252^{* * *}$ & 0.215 & $0.633^{* * *}$ \\
\hline & $(0.438)$ & $(0.405)$ & $(0.406)$ & $(0.519)$ & $(0.323)$ & $(0.375)$ & $(0.208)$ \\
\hline \multirow[t]{2}{*}{ SES } & $1.271^{* * *}$ & $0.954^{* * *}$ & 0.432 & $0.854^{* *}$ & 0.120 & $0.814^{* *}$ & $0.435^{* *}$ \\
\hline & $(0.359)$ & $(0.345)$ & $(0.393)$ & $(0.356)$ & $(0.302)$ & $(0.358)$ & $(0.195)$ \\
\hline \multirow[t]{2}{*}{ Region } & -0.109 & 0.111 & $-0.277^{*}$ & -0.281 & -0.181 & -0.0890 & $-0.177^{* *}$ \\
\hline & $(0.146)$ & $(0.137)$ & $(0.149)$ & $(0.177)$ & $(0.116)$ & $(0.146)$ & $(0.0744)$ \\
\hline \multirow[t]{2}{*}{ Right ideology } & $1.875^{* * *}$ & $1.599^{* * *}$ & $1.419^{* * *}$ & $1.515^{* * *}$ & $1.895^{* * *}$ & $2.527^{* * *}$ & $1.784^{* * *}$ \\
\hline & $(0.185)$ & $(0.190)$ & $(0.214)$ & $(0.176)$ & $(0.149)$ & $(0.235)$ & $(0.0927)$ \\
\hline \multirow[t]{2}{*}{ Center ideology } & -0.0627 & 0.0823 & $0.332^{*}$ & 0.259 & $0.444^{* * *}$ & $0.613^{* * *}$ & $0.458^{* * *}$ \\
\hline & $(0.206)$ & $(0.191)$ & $(0.184)$ & $(0.238)$ & $(0.151)$ & $(0.185)$ & $(0.0913)$ \\
\hline \multirow[t]{2}{*}{ Left ideology } & $-1.400^{* * *}$ & $-1.324^{* * *}$ & $-0.946^{* * *}$ & $-1.343^{* * *}$ & $-1.046^{* * *}$ & $-0.619^{* * *}$ & $-0.974^{* * *}$ \\
\hline & $(0.217)$ & $(0.188)$ & $(0.185)$ & $(0.338)$ & $(0.165)$ & $(0.205)$ & $(0.103)$ \\
\hline \multirow[t]{2}{*}{ Sociotropic } & -0.210 & $-0.854^{* *}$ & $1.864^{* * *}$ & $1.956^{* * *}$ & $2.306^{* * *}$ & $3.568^{* * *}$ & $2.376^{* * *}$ \\
\hline & $(0.397)$ & $(0.378)$ & $(0.433)$ & $(0.467)$ & $(0.310)$ & $(0.407)$ & $(0.197)$ \\
\hline \multirow[t]{2}{*}{ Sociotropic pro } & $0.605^{* *}$ & $0.557^{* *}$ & $1.834^{* * *}$ & $1.531^{* * *}$ & $1.055^{* * *}$ & -0.0959 & $1.235^{* * *}$ \\
\hline & $(0.260)$ & $(0.245)$ & $(0.264)$ & $(0.341)$ & $(0.211)$ & $(0.278)$ & $(0.135)$ \\
\hline \multirow[t]{2}{*}{ Egotropic } & $-0.887^{* *}$ & -0.555 & 0.292 & $1.166^{* *}$ & $0.592^{*}$ & -0.287 & 0.332 \\
\hline & $(0.420)$ & $(0.385)$ & $(0.486)$ & $(0.472)$ & $(0.344)$ & $(0.399)$ & $(0.215)$ \\
\hline \multirow[t]{2}{*}{ Egotropic pro } & 0.574 & 0.221 & $0.931^{* *}$ & $1.436^{* * *}$ & $1.433^{* * *}$ & $0.721^{*}$ & $1.161^{* * *}$ \\
\hline & $(0.424)$ & $(0.413)$ & $(0.443)$ & $(0.443)$ & $(0.313)$ & $(0.398)$ & $(0.200)$ \\
\hline \multirow[t]{2}{*}{ Dummy education } & -0.109 & -0.0825 & -0.213 & $-0.334^{*}$ & -0.0351 & -0.0661 & $-0.198^{* * *}$ \\
\hline & $(0.157)$ & $(0.147)$ & $(0.154)$ & $(0.192)$ & $(0.119)$ & $(0.141)$ & $(0.0756)$ \\
\hline \multirow[t]{2}{*}{ Dummy jobs } & $0.292^{*}$ & 0.0816 & -0.135 & 0.0416 & $-0.356^{* * *}$ & $-0.314^{*}$ & $-0.151^{*}$ \\
\hline & $(0.153)$ & $(0.144)$ & $(0.158)$ & $(0.194)$ & $(0.138)$ & $(0.189)$ & $(0.0825)$ \\
\hline \multirow[t]{2}{*}{ Dummy security } & $0.316^{* *}$ & 0.123 & 0.235 & 0.139 & -0.0259 & 0.152 & $0.136^{*}$ \\
\hline & $(0.148)$ & $(0.141)$ & $(0.166)$ & $(0.192)$ & $(0.116)$ & $(0.144)$ & $(0.0772)$ \\
\hline \multirow[t]{2}{*}{ Dummy health } & -0.00609 & -0.0704 & $0.307^{* *}$ & -0.0450 & -0.0731 & $0.248^{*}$ & 0.105 \\
\hline & $(0.149)$ & $(0.140)$ & $(0.147)$ & $(0.175)$ & $(0.112)$ & $(0.143)$ & $(0.0730)$ \\
\hline \multirow[t]{2}{*}{ Constant } & $-1.546^{* * *}$ & -0.133 & $-3.522^{* * *}$ & $-5.207^{* * *}$ & $-4.539^{* * *}$ & $-3.720^{* * *}$ & $-4.211^{* * *}$ \\
\hline & $(0.487)$ & $(0.441)$ & $(0.478)$ & $(0.461)$ & $(0.352)$ & $(0.451)$ & $(0.224)$ \\
\hline Observations & 1,264 & 1,264 & 2,659 & 2,828 & 4,158 & 2,681 & 12,326 \\
\hline
\end{tabular}

${ }^{* * *} \mathrm{p}<0.01,{ }^{* *} \mathrm{p}<0.05,{ }^{*} \mathrm{p}<0.1$ (two-tailed tests). Entries are unstandardized logistic regression coefficients, with standard errors in parenthesis.

Source: Authors, based on the Center for Public Studies Surveys \# 61-70 (www.cepchile.cl) 
Table 5. Change in Predicted Probabilities for Vote Intention and Presidential Approval

\begin{tabular}{|c|c|c|c|c|c|c|c|}
\hline \multirow{2}{*}{ Variables } & \multicolumn{2}{|c|}{ Vote Intention } & \multicolumn{5}{|c|}{ Presidential Approval } \\
\hline & 1R 2009 & 2R 2009 & 2010 & 2011 & 2012 & 2013 & Full Model \\
\hline \multirow[t]{2}{*}{ Sex } & $-0.0684^{* *}$ & -0.0496 & 0.0370 & -0.0202 & -0.0101 & 0.0384 & 0.00728 \\
\hline & $(0.0323)$ & $(0.0334)$ & $(0.0339)$ & $(0.0244)$ & $(0.0192)$ & $(0.0287)$ & $(0.0139)$ \\
\hline \multirow[t]{2}{*}{ Age } & -0.0113 & $-0.214^{* *}$ & 0.0344 & $0.147^{* *}$ & $0.219^{* * *}$ & 0.0447 & $0.127^{* * *}$ \\
\hline & $(0.0987)$ & $(0.100)$ & $(0.101)$ & $(0.0731)$ & $(0.0552)$ & $(0.0775)$ & $(0.0413)$ \\
\hline \multirow[t]{2}{*}{ SES } & $0.287^{* * *}$ & $0.236^{* * *}$ & 0.107 & $0.125^{* *}$ & 0.0210 & $0.169^{* *}$ & $0.0874^{* *}$ \\
\hline & $(0.0809)$ & $(0.0853)$ & $(0.0971)$ & $(0.0529)$ & $(0.0529)$ & $(0.0739)$ & $(0.0393)$ \\
\hline \multirow[t]{2}{*}{ Region } & -0.0245 & 0.0274 & $-0.0687^{*}$ & -0.0412 & -0.0316 & -0.0185 & $-0.0356^{* *}$ \\
\hline & $(0.0330)$ & $(0.0340)$ & $(0.0368)$ & $(0.0257)$ & $(0.0204)$ & $(0.0303)$ & $(0.0149)$ \\
\hline \multirow[t]{2}{*}{ Right ideology } & $0.432^{* * *}$ & $0.356^{* * *}$ & $0.331^{* * *}$ & $0.317^{* * *}$ & $0.428^{* * *}$ & $0.558^{* * *}$ & $0.415^{* * *}$ \\
\hline & $(0.0359)$ & $(0.0358)$ & $(0.0432)$ & $(0.0381)$ & $(0.0319)$ & $(0.0385)$ & $(0.0198)$ \\
\hline \multirow[t]{2}{*}{ Center ideology } & -0.0137 & 0.0204 & $0.0822^{*}$ & 0.0407 & $0.0826^{* * *}$ & $0.129^{* * *}$ & $0.0953^{* * *}$ \\
\hline & $(0.0449)$ & $(0.0473)$ & $(0.0457)$ & $(0.0391)$ & $(0.0295)$ & $(0.0413)$ & $(0.0198)$ \\
\hline \multirow[t]{2}{*}{ Left ideology } & $-0.222^{* * *}$ & $-0.267^{* * *}$ & $-0.198^{* * *}$ & $-0.123^{* * *}$ & $-0.124^{* * *}$ & $-0.0950^{* * *}$ & $-0.139^{* * *}$ \\
\hline & $(0.0294)$ & $(0.0332)$ & $(0.0357)$ & $(0.0228)$ & $(0.0175)$ & $(0.0282)$ & $(0.0128)$ \\
\hline \multirow[t]{2}{*}{ Sociotropic } & -0.0472 & $-0.211^{* *}$ & $0.461^{* * *}$ & $0.287^{* * *}$ & $0.403^{* * *}$ & $0.740^{* * *}$ & $0.478^{* * *}$ \\
\hline & $(0.0896)$ & $(0.0935)$ & $(0.108)$ & $(0.0653)$ & $(0.0530)$ & $(0.0798)$ & $(0.0392)$ \\
\hline \multirow[t]{2}{*}{ Sociotropic pro } & $0.136^{* *}$ & $0.138^{* *}$ & $0.454^{* * *}$ & $0.224^{* * *}$ & $0.184^{* * *}$ & -0.0199 & $0.248^{* * *}$ \\
\hline & $(0.0585)$ & $(0.0606)$ & $(0.0654)$ & $(0.0552)$ & $(0.0374)$ & $(0.0576)$ & $(0.0278)$ \\
\hline \multirow[t]{2}{*}{ Egotropic } & $-0.200^{* *}$ & -0.137 & 0.0723 & $0.171^{* *}$ & $0.103^{*}$ & -0.0595 & 0.0667 \\
\hline & $(0.0948)$ & $(0.0953)$ & $(0.120)$ & $(0.0708)$ & $(0.0602)$ & $(0.0827)$ & $(0.0434)$ \\
\hline \multirow[t]{2}{*}{ Egotropic pro } & 0.130 & 0.0546 & $0.231^{* *}$ & $0.210^{* * *}$ & $0.250^{* * *}$ & $0.150^{*}$ & $0.233^{* * *}$ \\
\hline & $(0.0955)$ & $(0.102)$ & $(0.109)$ & $(0.0630)$ & $(0.0546)$ & $(0.0817)$ & $(0.0396)$ \\
\hline \multirow[t]{2}{*}{ Dummy education } & -0.0245 & -0.0204 & -0.0526 & $-0.0489^{*}$ & -0.00612 & -0.0137 & $-0.0396^{* * *}$ \\
\hline & $(0.0352)$ & $(0.0362)$ & $(0.0378)$ & $(0.0284)$ & $(0.0207)$ & $(0.0292)$ & $(0.0151)$ \\
\hline \multirow[t]{2}{*}{ Dummy jobs } & $0.0665^{*}$ & 0.0202 & -0.0333 & 0.00614 & $-0.0587^{* * *}$ & $-0.0626^{*}$ & $-0.0298^{*}$ \\
\hline & $(0.0352)$ & $(0.0356)$ & $(0.0388)$ & $(0.0289)$ & $(0.0214)$ & $(0.0359)$ & $(0.0160)$ \\
\hline \multirow[t]{2}{*}{ Dummy security } & $0.0709^{* *}$ & 0.0303 & 0.0581 & 0.0204 & -0.00453 & 0.0315 & $0.0273^{*}$ \\
\hline & $(0.0330)$ & $(0.0347)$ & $(0.0406)$ & $(0.0279)$ & $(0.0202)$ & $(0.0299)$ & $(0.0154)$ \\
\hline \multirow[t]{2}{*}{ Dummy health } & -0.00137 & -0.0174 & $0.0761^{* *}$ & -0.00658 & -0.0127 & $0.0514^{*}$ & 0.0212 \\
\hline & $(0.0335)$ & $(0.0345)$ & $(0.0364)$ & $(0.0255)$ & $(0.0195)$ & $(0.0296)$ & $(0.0148)$ \\
\hline$N$ & 1,264 & 1,264 & 2,659 & 2,828 & 4,158 & 2,681 & 12,326 \\
\hline
\end{tabular}

${ }^{* * *} p<0.01,{ }^{* *} p<0.05,{ }^{*} p<0.1$ (two-tailed tests). Entries represent change in probabilities.

Source: Authors, based on the Center for Public Studies Surveys \# 61-70 (www.cepchile.cl) 


\section{CONCLUSION}

As the first rightwing president democratically elected in Chile after the Pinochet dictatorship, Sebastián Piñera (2010-2014) was also the first president to see his approval decline rapidly after taking office. Using CEP polls conducted under his presidency, we show that the strongest predictor of presidential approval for Piñera were rightwing ideology and economic vote variables. There is also partial evidence that approval was explained by the salience of issues-such as education and crime prevention-and that the cost of ruling had an effect on presidential approval, as those who considered jobs to be a priority for government action were less likely to approve of Piñera in the second half of his administration.

Although the economic vote variables, the salience of issues, and the cost of ruling as determinants of presidential approval have explanatory power in accounting for the fluctuations-and the downward trend-in Piñera's approval, the fact that Piñera experienced a rapid decline in his approval shortly after taking power also provides support for the punishment vote against the incumbent government hypothesis. When comparing the determinants of vote choice for Piñera in the first-round and runoff elections with the determinants of presidential approval, we find evidence of what we ironically refer to as a onenight stand. Piñera's victory is partially explained by a protest vote against the Concertación's twenty-year tenure. After those voters abandoned Piñera in his first year in office, the determinants of Piñera's presidential approval behaved in the way they normally do to account for presidential approval. Though some voters abandoned Piñera because of discrepancies based on priorities for government action-and others abandoned him as a result of the cost of ruling - the determinants of support for Piñera are explained by economic vote variables. Those who perceived the economy as going well were more likely to support President Piñera.

Piñera's record-breaking low presidential approval cannot be solely explained by economic voting. Admittedly, the fact that a large percentage of Chileans had neutral present and prospective views on the economy might be surprising given the progress the economy made under Piñera. Perhaps, economic perceptions themselves can be explained by variables associated to ideology or other endogenous variables that account for people's views. People who were less inclined to approve of Piñera might have held views on the economy that were less optimistic than the economic figures would have indicated. Still, fluctuations in presidential approval under Piñera can be explained by economic voting and, to a lesser extent, by the salience of popular priorities for government action.

The case of Chile under Piñera also contributes to the understanding of how the determinants of presidential approval behave in cases where alternation in power happens after a long tenure by an ideologically opposite government. When that alternation takes place under improving economic conditions and the 
new government presides over a period of economic expansion, the economic vote determinants might have a significant effect on explaining fluctuations in presidential approval, but they do not tell the whole story. Other variables, including the effect of a punishment vote against the previous government, issue salience and cost of ruling also affect the way in which presidential approval evolves.

Sebastián Pinera might have become president as a result of a one-night stand with voters who were dissatisfied with the Concertación's twenty-year run, and his approval might have been affected by issue salience and cost of ruling effects, but insofar as present and prospective socio-tropic assessments and prospective egotropic assessments are concerned, economic vote models explain fluctuations in presidential approval between 2010 and 2014.

\section{REFERENCES}

Arce, Moisés. 2003. "Political Violence and Presidential Approval in Peru." Journal of Politics 65 (2): 572-583.

Arce, Moisés and Julio Carrión. 2010. "Presidential Support in a Context of Crisis and Recovery in Peru, 1985-2008." Journal of Politics in Latin America 2 (1): 31-51.

Bartels, Larry M. 2011. "The Study of Electoral Behavior." In The Oxford Handbook of American Elections and Political Behavior, edited by Jan E Leighley. New York: Oxford University Press, 239-261.

Booth, John A. and Mitchell A. Seligson. 2009. The Legitimacy Puzzle in Latin America: Political Support and Democracy in Eight Nations. New York: Cambridge University Press.

Cabezas, José Miguel and Patricio Navia. 2010. "Aprobación presidencial en el cuatrienio de Bachelet." In Chile 2009. Percepciones y actitudes sociales, edited by Claudio Fuentes. Santiago: ICSO-UDP, 17-26.

Campbell, Angus, Pihilip E. Converse, Warren E. Miller and Donald E. Stokes. 1960. The American Voter. New York: Wiley.

Canes-Wrone, Brandice and Scott de Marchi. 2002. "Presidential Approval and Legislative Success." Journal of Politics 64 (2): 491-509.

Carlin, Ryan E. and Matthew M. Singer. 2015. The Latin American Voter: Pursuing Representation and Accountability in Challenging Contexts. Ann Arbor: University of Michigan Press.

Cataife, Guido. 2011. "An Integrated Model of Vote Choice in Argentina, 2009." Latin American Politics and Society 53 (3): 115-140.

Centro de Estudios Públicos. 2018. Encuesta CEP. Data file and codebook. Retrieved from https://www.cepchile.cl/cep/site/edic/base/port/encuestacep.html

Contreras, Gonzalo and Patricio Navia. 2013. "Diferencias generacionales en la participación electoral en Chile, 1988-2010." Revista de Ciencia Politica 33 (2): 419-441.

Converse, Pihilip E. 1964. The Nature of Belief Systems in Mass Publics. Ideology and Discontent. New York: Free Press.

Córdova, Abby and Mitchell A. Seligson. 2010. "Economic Shocks and Democratic Vulnerabilities in Latin America and the Caribbean." Latin American Politics and Society 52 (2): 1-35.

Downs, Anthony. 1957. An Economic Theory of Democracy. New York: Harper \& Row.

Duch, Raymond and Randy Stevenson. 2005. "Context and the Economic Vote: A Multilevel Analysis." Political Analysis 13 (4): 387-409.

Duch, Raymond and Randolph Stevenson. 2008. The Economic Vote. How Political and Economic Institutions Condition Election Results. New York: Cambridge University Press. 
Duggan, John and Mark Fey. 2005. "Electoral Competition with Policy-Motivated Candidates." Games and Economic Behavior 51 (2): 490-522.

Edwards, Georg C. III. 1997. "Aligning Tests with Theory: Presidential Approval as a Source of Influence in Congress." Congress and the Presidency 24 (2): 113-30.

Elacqua, Gregory and Cristóbal Aninat. 2013. "Chile's Pragmatic Middle-Class Voter." Americas Quarterly 7 (1): 38.

Erikson, Robert S., Michael B. MacKuen and James A. Stimpson. 2002. The Macro Polity. New York: Cambridge University Press.

Erikson, Robert S., Michael B. MacKuen and James A. Stimpson. 2000. "Bankers or Peasants Revisited: Economic Expectations and Presidential Approval." Electoral Studies 19 (2/3): 295-312.

Ferejohn, John. 1986. "Incumbent Performance and Electoral Control." Public Choice 50 (1): 5-25.

Fiorina, Morris. 1981. Retrospective Voting in American National Elections New Haven, CT: Yale University Press.

Gélineau, François. 2007. "Presidents, Political Context, and Economic Accountability." Political Research Quarterly 60 (3): 415-428.

Hawkins, Kirk, Jean Ann Patch, Adam Anguiano and Mitchell Seligson. 2008. Political Culture of Democracy in Venezuela: 2007. Nashville, TN: LAPOP/Vanderbilt University.

Jennings, M.K. and R.G. Niemi. 1968. "The Transmission of Political Values from Parent to Child." American Political Science Review 62 (1): 169-184.

Kim, J., Elliott, E. and Wang, D. M. 2003. A Spatial Analysis of County-Level Outcomes in US Presidential Elections: 1988-2000. Electoral Studies 22 (4): 741-761.

Knutsen, Oddbjorn. 2007. "The Decline of Social Class?" In The Oxford Handbook of Political Behavior, edited by Russel J Dalton and Hans-Dieter Klingemann. New York: Oxford University Press, 457-480.

Kramer, Gerald H. 1971. "Short Term Fluctuation in U.S. Voting Behavior 1896-1964." American Political Science Review 63 (1): 131-143.

Kriner, Douglas and Liam Schwartz. 2009. "Partisan Dynamics and the Volatility of Presidential Approval." British Journal of Political Science 39 (3): 609-631.

Lau, Richard R. and David P. Redlawsk. 2006. How Voters Decide. Information Processing During Elections Campaigns. New York: Cambridge University Press.

Lazarsfeld, Paul, Bernard Berelson and Hazel Gaudet. 1944. The People's Choice. New York: Columbia University Press.

Lewis-Beck, Michael. 1988. Economics and Elections: The Major Western Democracies. Ann Arbor: University of Michigan Press.

Lewis-Beck, Michael S. and María Celeste Ratto. 2013. "Economic Voting in Latin America: A General Model." Electoral Studies 32 (3): 489-493.

Lewis-Beck, Michael S. and Mary Stegmaier. 2007. “Economic Models of Voting." In The Oxford Handbook of Political Behavior, edited by Russel J Dalton and Hans-Dieter Klingemann. New York: Oxford University Press, 518-537.

Lipset, Seymour and Stein Rokkan. 1967. "Cleavage Structures, Party Systems and Voter Alignments: An Introduction." In Party Systems and Voter Alignment, edited by S Seymour Martin Lipset and Stein Rokkan. New York: Free Press, 1-64.

Luna, Juan Pablo. 2008. "Democracia, Gobierno y Partidos: Introducción a LAPOP Chile 2008." Revista de Ciencia Política 28 (3): 115-141.

Luna, Juan Pablo and Sergio Toro Maureira. 2010. “The Chilean Elections of December 2009 and January 2010". Electoral Studies 30 (1): 226-230.

Morales, Mauricio. 2008. “La primera mujer presidenta de Chile. ¿Que explicó el triunfo de Michelle Bachelet en las elecciones de 2005-2006?" Latin American Research Review 43 (1): 7-32.

Morales, Mauricio. 2015. “Debut y despedida. La derecha chilena en las elecciones presidenciales 2013." Revista de Estudios Políticos (Nueva Época) 168 (Abril-Junio): 261-290. 
Morgan, Jana. 2003. "Courting the Past or Investing the Future? Economic and Political Accountability in Fujimori's Peru." Journal of Politics 65 (3): 864-880.

Nadeau, Richard, Richard G. Niemi, David P. Fan and Timothy Amato. 1999. "Elite Economic Forecasts, Economic News, Mass Economic Judgments, and Presidential Approval." Journal of Politics 61 (1): 109-135.

Nannestad, P. and M. Paldam. 1997. "From the Pocketbook of the welfare Man: A Pooled Cross-Section Study of Economic Voting in Denmark, 1986-92." British Journal of Political Science 27 (1): 119-136.

Nannestad, Peter and Martin Paldam. 1994. "The VP-Function: A Survey of the Literature on Vote and Popularity Functions After 25 Years." Public Choice 79 (3-4): 213-245.

Navia, Patricio and Mauricio Morales. 2010. "Prólogo." In El sismo electoral de 2009. Cambio y continuidad en las preferencias políticas de los chilenos, edited by Patricio Navia and Mauricio Morales. Santiago: Ediciones Universidad Diego Portales, 9-56.

Ostrom, Charles W. Jr., Alon P. Kraitzman, Brian Newman and Paul R. Abramson. 2017. "Polls and Elections: Terror, War, and the Economy in George W. Bush's Approval Ratings: The Importance of Salience in Presidential Approval." Presidential Studies Quarterly 48 (2): 318-341.

Paldam, Martin. 1986. "The Distribution of Election Results and the Two Explanations of the Cost of Ruling." European Journal of Political Economy 2 (1): 5-24.

Panzer, John and Ricardo D. Paredes. 1991. "The Role of Economic Issues in Elections: The Case of the 1988 Chilean Presidential Referendum." Public Choice 71 (1-2): 51-59.

Perelló, Lucas. 2015. "One of These Things is Sort of Like the Other: Presidential Approval and Support for Government Management of the Economy in Chile, 2006-2013." Revista de Ciencia Política 53 (1): 117-164.

Powell, G. Bingham Jr. and Guy D. Whitten. 1993. "A Cross-National Analysis of Economic Voting: Taking Account of the Political Context." American Journal of Political Science 37 (2): 391-414.

Remmer, Karen L. 1991. "The Political Impact of Economic Crisis in Latin America in the 1980s." The American Political Science Review 85 (3): 777-800.

Remmer, Karen L. and François Gélineau. 2003. "Subnational Electoral Choice Economic and Referendum Voting in Argentina, 1983-1999." Comparative Political Studies 36 (7): 801821.

Richardson, Bradley M. 1991. "European Party Loyalties Revisited." The American Political Science Review 85 (3): 751-775.

Roberts, Kenneth M. and Erik Wibbels. 1999. "Party Systems and Electoral Volatility in Latin America: A Test of Economic, Institutional, and Structural Explanations." American Political Science Review 93 (3): 575-590.

Romero, Vidal. 2009. “La herencia del presidente.” Política y gobierno 16 (1): 3-35

Segovia, Carolina, Andrés Haye, Roberto González, Jorge Manzi and Héctor Carvacho. 2008. "Confianza en instituciones políticas en Chile: un modelo de los componentes centrales de juicios de confianza." Revista de Ciencia Política 28 (2): 39-60.

Seligson, Mitchell, and Amy Erica Smith. 2010. Political Culture of Democracy, 2010. Democratic Consolidation in the Americas in Hard Times: Report on the Americas. Nashville: LAPOP.

Servicio Electoral de Chile. Resultados Históricos. Retrieved from https:/ /historico.servel.cl/

Stokes, Susan C. 2001. Public Support for Market Reforms in New Democracies. New York: Cambridge University Press.

Varas, Augusto. 2014. El gobierno de Piñera (2010-2014). Santiago: Catalonia.

Ventura, Raphael. 2001. "Family Political Socialization in Multiparty Systems." Comparative Political Studies 34 (6): 666-691.

Weyland, Kurt. 1998. "Peasants or Bankers in Venezuela? Presidential Popularity and Economic Reform Approval, 1989-1993." Political Research Quarterly 51 (2): 341-362.

Weyland, Kurt. 2000. "A Paradox of Success? Determinants of Political Support for President Fujimori." International Studies Quarterly 44 (3): 481-502.

World Bank. Open Data. Retrieved from https://data.worldbank.org/country/chile 
Received: July 22, 2017

Accepted: June 2, 2018

Patricio Navia es doctor en ciencia política (New York University, 2003). Es profesor titular de ciencia política en Universidad Diego Portales y Clinical Professor of Liberal Studies en New York University. Ha publicado varios artículos sobre elecciones, opinión pública y partidos políticos en diversas revistas y libros. Correo electrónico: patricio.nava@nyu.edu

Lucas Perelló es PhD Candidate in Politics en The New School for Social Research. Es magister en Applied Quantitative Research en New York University y magister en ciencia política en la Pontificia Universidad Católica de Chile. Ha publicado artículos y capítulos de libros sobre voto económico y comportamiento electoral. Correo electrónico: perel531@newschool.edu 